
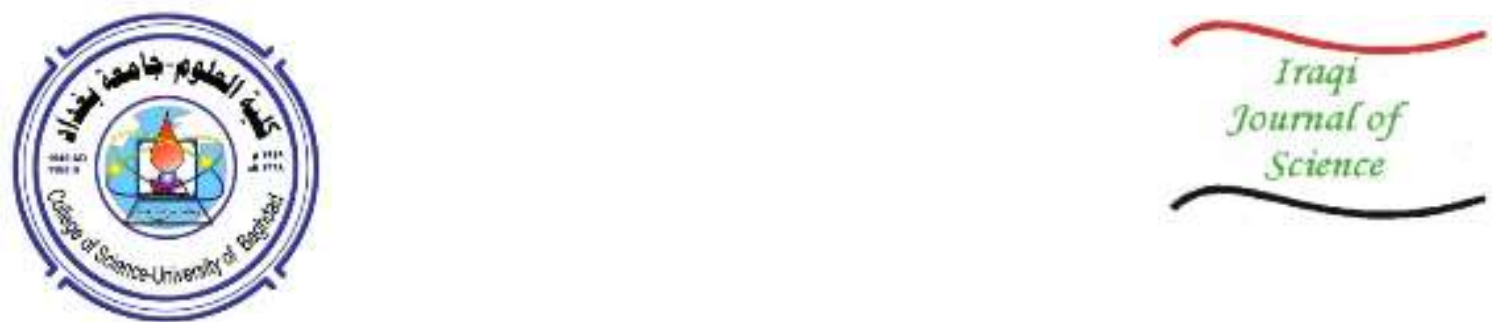

\title{
Geology and Structural Description of Shakrok Anticline; Northern Iraq
}

\author{
Sally Hussin Ahmed, Mahmood Abd ALAmeer Salman* \\ Department of Geology, College of Science, University of Baghdad, Baghdad, Iraq
}

Received: 25/10/2019 Accepted: 30/11/2019

\begin{abstract}
The studied area is a part of the Arabian plate located within the High Folded Zone of the Zagros Fold-Thrust Belt in northeastern Iraq (Kurdistan Region). The Study area deals with the Shakrok Anticlines is located between Safin Mountain and Sork Mountain. These structures are formed during the Alpine Orogeny in Cretaceous-Tertiary period. Generally, the folded structures are trending NW-SE direction which is parallel to the main Zagros Orogenic trends.

The exposed stratigraphic succession of the studied area that represented by 4 formations deposited from the Early Cretaceous which are Shiranish, Aqrah, Bekhme and Qamchuqa formations. Shakrok Anticline are asymmetrical, double plunging and verging toward northeast. This establishes that Merawa is a Tertiary continuation part of Cretaceous Shakrok Anticline, but there is a deflection in the direction of the fold axis that affected the Merawa Anticline due to the effect of strike slip fault addition to Lineament. Shakrok Anticline with Cretaceous successions formed due to the effect of Cretaceous and Tertiary folding phases. But Merawa Anticline with Tertiary succession that formed due to the effect of Tertiary folding phases.

The high stress and intensity of the major fault on the southwestern limb rotated and overturned Tertiary successions and changed its dip toward NE.

The differences in fold geometry, fold axis, axial surface, and curvilinear hinge imply that the structure formed as a result of two folding phases \& lateral growth of folds that developed by changing the direction of the compressional tectonic processes due to Alpine Orogene of Zagros. The fold axis of Shakrok Anticline rotated $16^{\circ}$ in anticlockwise trend from Merawa to Sork anticlines. Because of anticlockwise rotation of the Arabian plate due to its collision with Iranian and Anatolian plates.
\end{abstract}

Keywords: Geology, Structural description, Shakrok Anticline, Northern Iraq

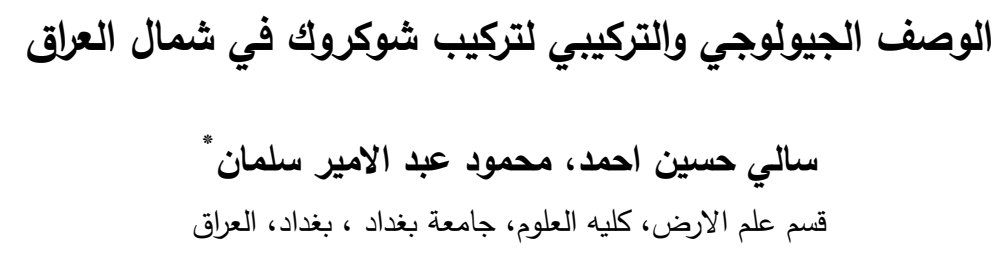




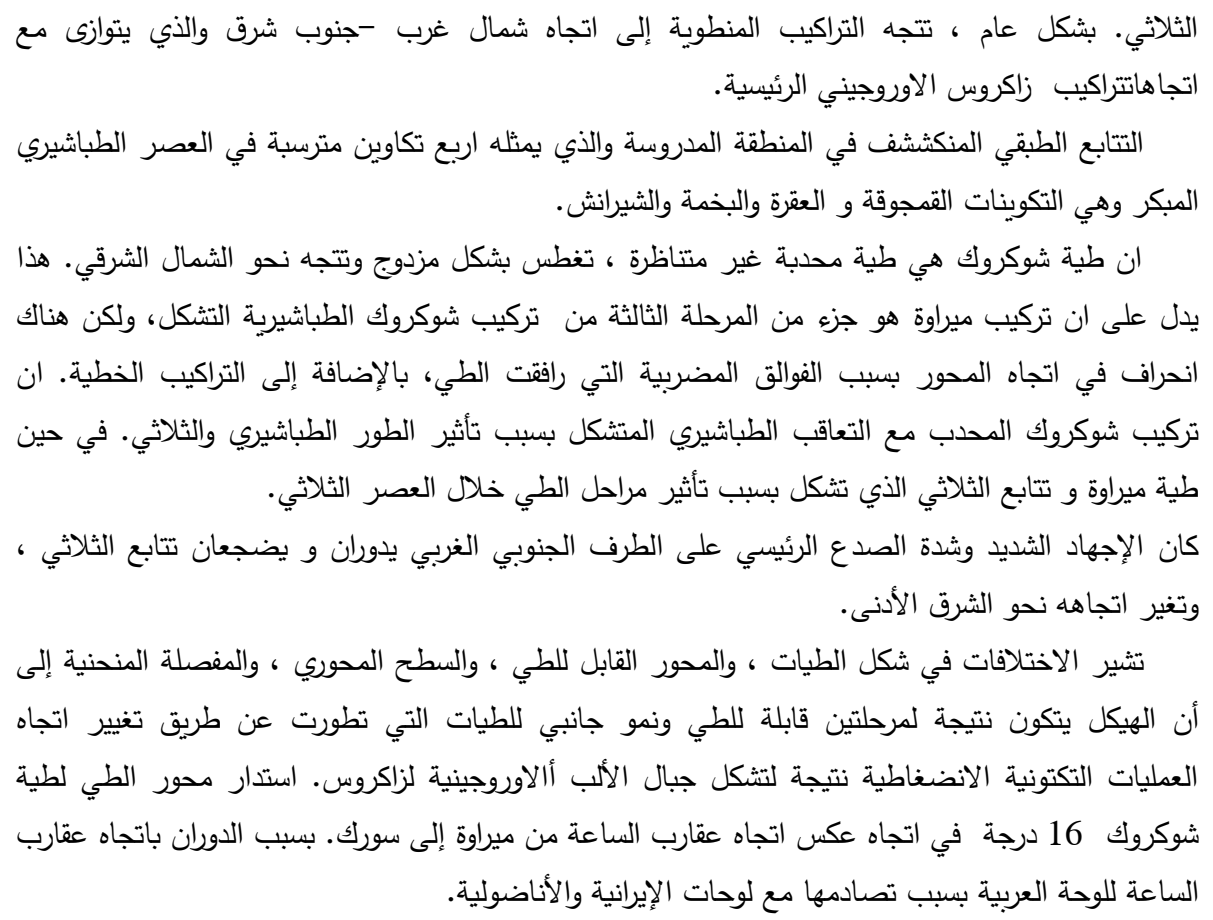

\section{Introduction}

Despite there are some geological and structural researches were achieved in the north and northeastern part of Iraq, but the study of structural analysis is still lack to characterize the structural model for the Shakrok anticline. In the present day the northern and northeast part of Iraq (Kurdistan region) has been a subject for numerous geological and geophysical investigations, since the earliest days of petroleum discoveries in this region.

The fold axes in the studied area are characterized by change in direction. These axes tend to be east to west direction in the north and northwestern part of the study area, while in the southern and southeastern part till the Greater Zab River it becomes corresponding with the north west to southeast direction [1] (Figure-1).Structurally the area is located within the northwestern segment of the Zagros fold thrust belt [2]. Typically, the study area represent partition of High Folded Zone , which oriented on a northwest to southeast trend in northeastern Iraq and east to west in northern Iraq. The folds are mostly asymmetrical with steeper south or southwest dipping limbs and sometimes with thrust fault in the steeper limb [3].The High Folded Zone forming an arch shaped belt with different widths.

The study area located in Erbil northern Iraq which situated between Safin and Sork Mountains, with a height about $1066 \mathrm{~m}$ above sea level, with longitude $\mathrm{E}\left(43^{\circ} 36^{\prime \prime} 00^{\prime}-36^{\circ} 35^{\prime \prime} 00^{\prime}\right)$ and latitude $\mathrm{N}\left(45^{\circ}\right.$ 39" 00' _ 4519" 00' ) (Fig.1). 


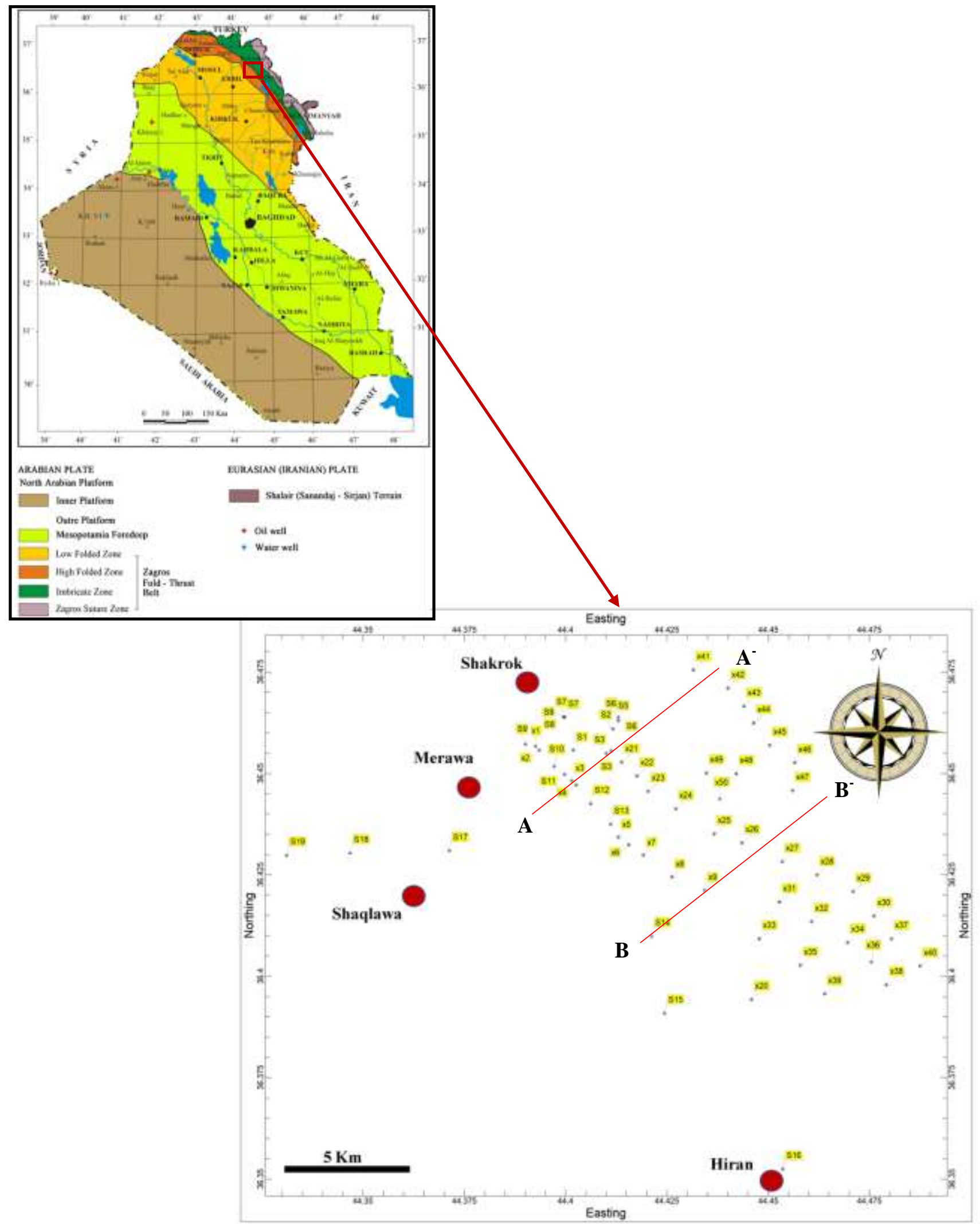

Figure 1-Location map of the study area with tectonic position according to (Fouad, 2014) Aim of Study

1- Geometrical analysis of the Shakrock structures.

2- Classification of fracture systems within the study area.

3- Construct a tectonic model to describe the history of the development of the study area . 


\section{Materials and Methods}

Structural geological investigation requires extensive field observation on the surface and geophysical data, in addition to satellite images and digital elevation model to better understand the geomorphologic features.

The data in this study mainly acquired from observation and direct field measurements from various structures that were carried out in 50 field stations. The field data have been taken along four traverses across the fold axes (perpendicular to the fold axis). The first reconnaissance field trip was started at 15/4/2019 and field work continued to 5 days, and the second reconnaissance field trip was started at 1/7/2019 and continued to 7 days were carried during the progress of office work and data analysis for checking stations and adding another station because the limited outcrops.

Two sheets of topographic maps of scale 1:25000 and 1:100000, GPS reading data and coordination of the base map, Landsat satellite image (Landsat7 ETM and Landsat 8). Also, Brunton compass was used for measuring attitude for the planar and linear structural features. These tools were used to measuring the attitude of bedding planes, description of the lithological composition, remarks about the formation and bed thickness, Plotting geologic formation boundaries on the base map and coordination and elevation of each station.

The collected data during field work and remote sensing data which include Landsat satellite images and Aster Digital Elevation Models (DEM) were used for analysis and interpretation. All the obtained data were first represented graphically by hand method and using different types of computer software. The results were used in geometrical analysis for the folds.

Many types of software were used for analyzing the obtained data and representation of maps or structural trends for folds within the studied area. Following is the brief description of utilized software;GEOrient 9.5, GeoCalculator 4.9.3 and Rockwork 15, 2009.

\section{Geological setting}

The studied area is built up of sedimentary rocks ranging in age from Early Cretaceous Maastrichtian, beside various types of Quaternary sediments, the exposed formations are described briefly (from older to younger) (Figures-(2, 3):

\section{Qamchuqa Formation (Huterivian - Albain)}

The Qamchuqa Formation was described from the Qamchuqa Gorge by Wetzel 1950 in NE Iraq [4]. It is exposed in the core of the Shakrok Anticline within the deep valleys. Lower part of Qamchuqa Formation is not cropped out in the study area. But the upper part composed mainly of limestone and dolomites.

Pale yellowish in color, hard to very hard, well bedded to massive, fractured dolomite and limestones. Lower contact of this formation cannot be seen in the studied area, but according to data obtained from exploration wells from Harir and Mirawa its thickness is about 437 and $450 \mathrm{~m}$ respectively [5]. The upper contact is unconformable with the Bekhme Formation marked by conglomerate and is underlain by Sarmord Formation. Ameen (2008) [6] believes that the Qamchuqa Formation was mainly deposited in the reef, backreef, forereef and lagoon environments. Because of massive and hard nature of this formation is regarded as a competent formation.

\section{Aqra-Bekhme Formation (Campanian-Maastrichtian)}

The Aqra Formation was defined by Bennett in 1945 [3] from the Aqra anticline in the High Folded Zone of Northern Iraq as a reef limestone complex with massive rudists, shoal facies, and detrital forereef limestone. It is locally dolomitised, siliceous, and impregnated with bitumen.

This formation exposed at the body of Shakrok anticline core underlying of Bekmah Formation and overlaying of Qamchuaq Formation. its characterized by well bedded of sallow marine limestone associated facies. The formation consists mainly of limestone and dolomite beds which characterized by grey and grayish brown in color, hard to very hard, well bedded to massive[7].

The Bekhme Formation consists mainly of limestone and dolomite. The limestone is light gray and grayish brown in color, hard, thick bedded to massive. The thickness of some beds exceeds $6 \mathrm{~m}$ but generally they range from $0.5-2 \mathrm{~m}$. Lower part well bedded, composed of conglomerate and bituminous materials. The middle unit is composed of coral reef limestone, thickly bedded. But the upper part is the thickest unit that composed of very hard dolomite and contains large rudist debris. 


\section{Shiranish Formation (Maastrichtian)}

The Shiranish Formation, in the type section, comprises of thin bedded argillaceous limestones (locally dolomitic) in the lower part, while the upper part is blue pelagic marls (Owen and Nasr, 1958; Bellen et al., 1959 in [3]).

The microfacies analysis showing two major successions with Red Bed and Non-Red Bed marl and marly limestone, occasionally interbedded with thinly beds of shale, sandstone and siltstone [8].

This formation exposed at the two limbs of the Shakrok anticline and surrounding area. The formation consists of two parts; the upper part is characterized by soft rock as a shale, while the lower is limestone frequently marly or clayey dominated rocks as well bedded.

\section{Quaternary Sediments}

Quaternary deposit are represented by Questa-Hogback, ride, cliff and badland are the most dominant geomorphological erosion features, which mainly control by structural and lithological properties, parallel type of drainage pattern are very common. The Quaternary sediments include the following types:

* Slope Sediments (Pleistocene - Holocene)

These are developed mainly in the steep side of Shakrok anticline and near the core in small patches. They usually consist of gravel, which are derived from oldest formations. The thickness of these sediments varies from $20 \mathrm{~cm}$ to $1.5 \mathrm{~m}$.

* Residual Soil (Holocene)

It is developed in small part only (near the river terraces) and it is mainly composed of clayey and silty types. The thickness varies from $20 \mathrm{~cm}$ to $1.0 \mathrm{~m}$.

* Valley Fill Sediments (Holocene)

These sediments are developed in Shakrok syncline and surrounding valleys. They consist mainly of gravels of different sizes, sand and silt. The thickness of these sediments are ranging from less than one meter to $2 \mathrm{~m}$.

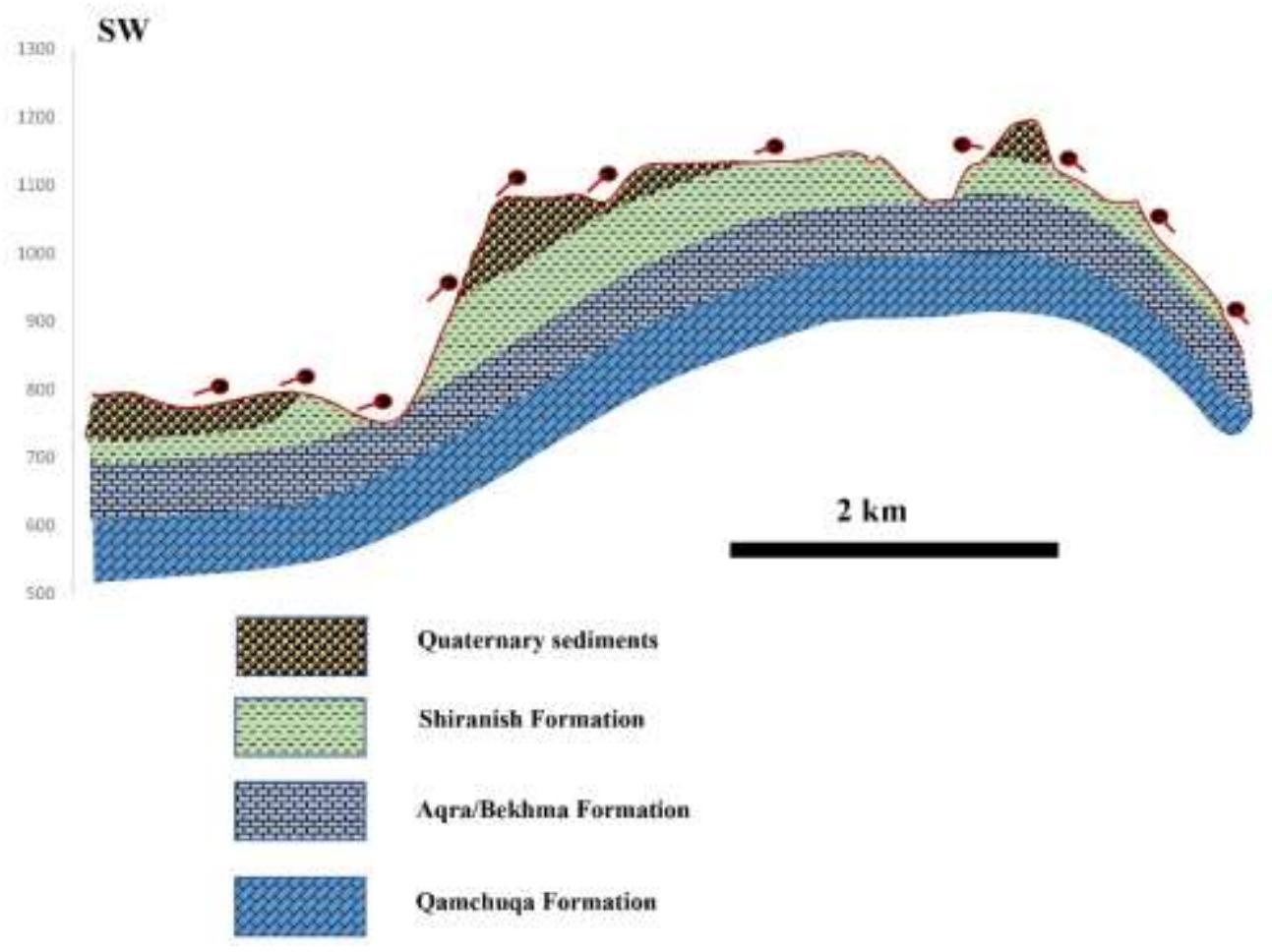

Figure 2-Geological cross section of Shakrok Anticline along cross section (A-A-) 


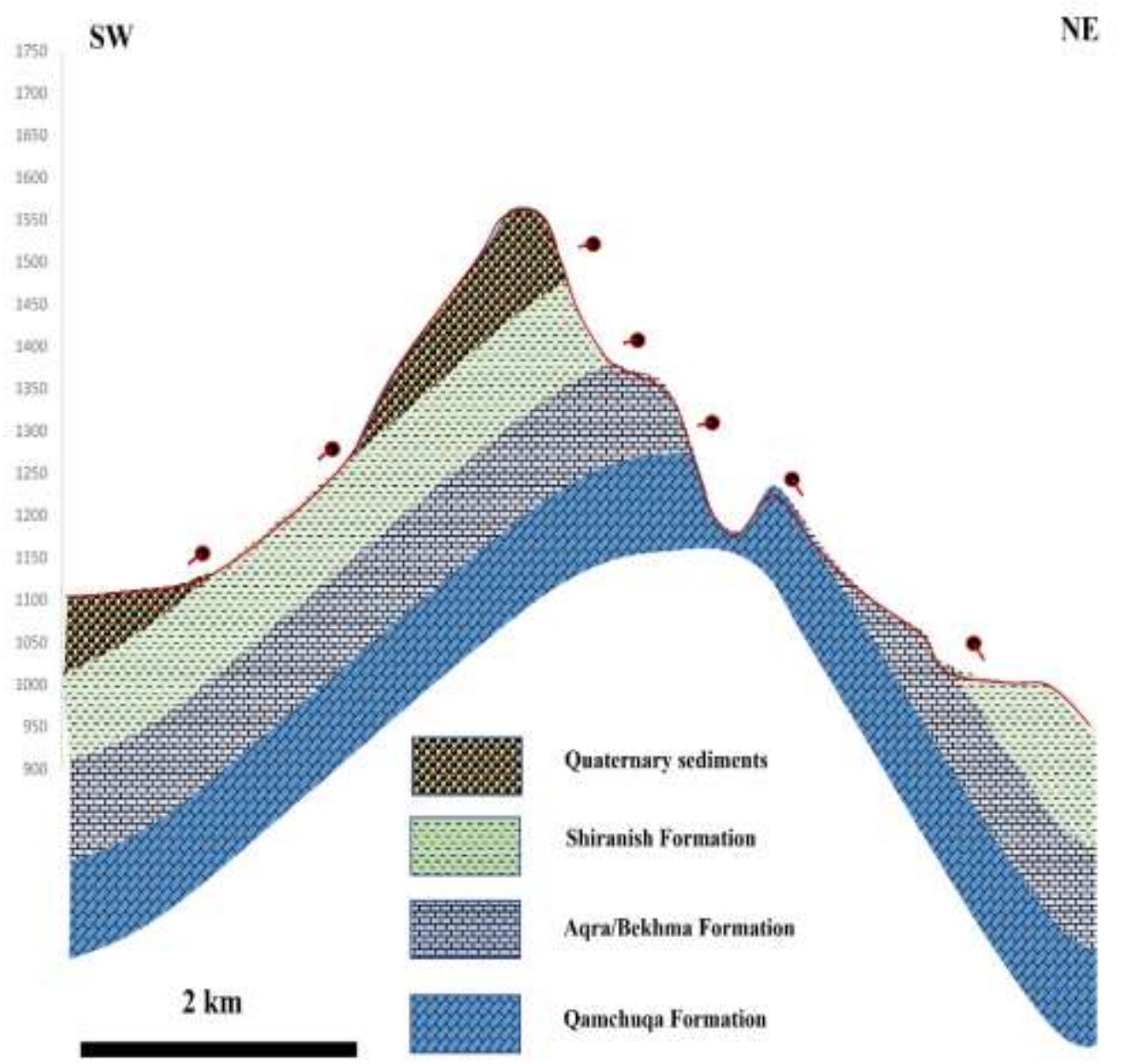

Figure 3-Geological cross section of Shakrok Anticline along cross section (B-B')

\section{General Field Description of Shakrok Anticline:}

Shakrok Anticline is asymmetrical fold as the northeast limb $\left(48^{\circ}\right)$ is steeper and shorter than the southwest limb about $\left(33^{\circ}\right)$ near the northwest plunge, while near the south east plunge about $80^{\circ}$ as steeper side (northeast limb) and $44^{\circ}$ for the southwest limb. The axial length of the maximum topography from the profile section is about $22 \mathrm{~km}$ and maximum width about $6 \mathrm{~km}$ (Figures- $(4,5)$ as extracted from the SAS.Planet software.

Merawa-Shakrok Anticline is one of the major structures in the Foreland Folds Belt of Iraq. Its length is about $65 \mathrm{~km}$ as measured from Satellite image. The previous researchers like Al-Shaikh et al. (1975)[9] and Ghaib et al. (2009)[10] believe that Merawa Anticline is separated structure from Shakrok Anticline, while Al-Dawoody (2004)[11]; Numan (2002) in [10] and Omar (2005)[12] considered that Merawa (Khatibian) Anticline is a Tertiary folded part of Shakrok Anticline that bended in the axis of Shakrok to the northwest which is agree with the present work. Al- Dawoody (2004) [11] depending on the gravity interpretation established that Merawa Anticline is part of the Shakrok Anticline. Omar (2005)[12] studied this structure and described the characteristics of this anticline. He divided this structure across the axis into Skakrok and Merawa anticlines, the central and southeastern sector called Shakrok Anticline that characterized by Cretaceous succession and high altitudes, while the northwestern part of the anticline that called Merawa Anticline characterized by Tertiary successions and low altitudes. 


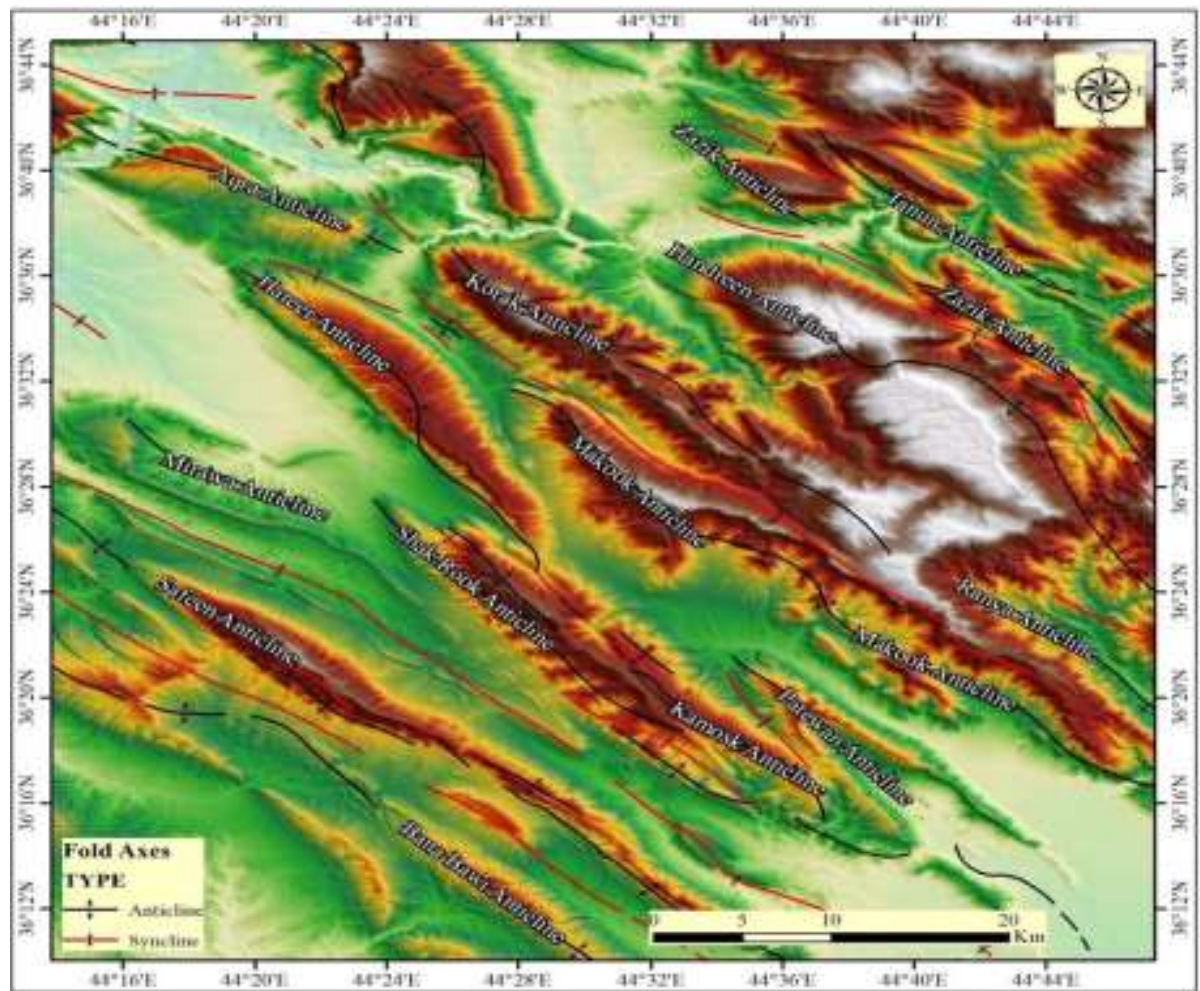

Figure 4-Landsat satellite image shows Shakrok-Merawa anticline.

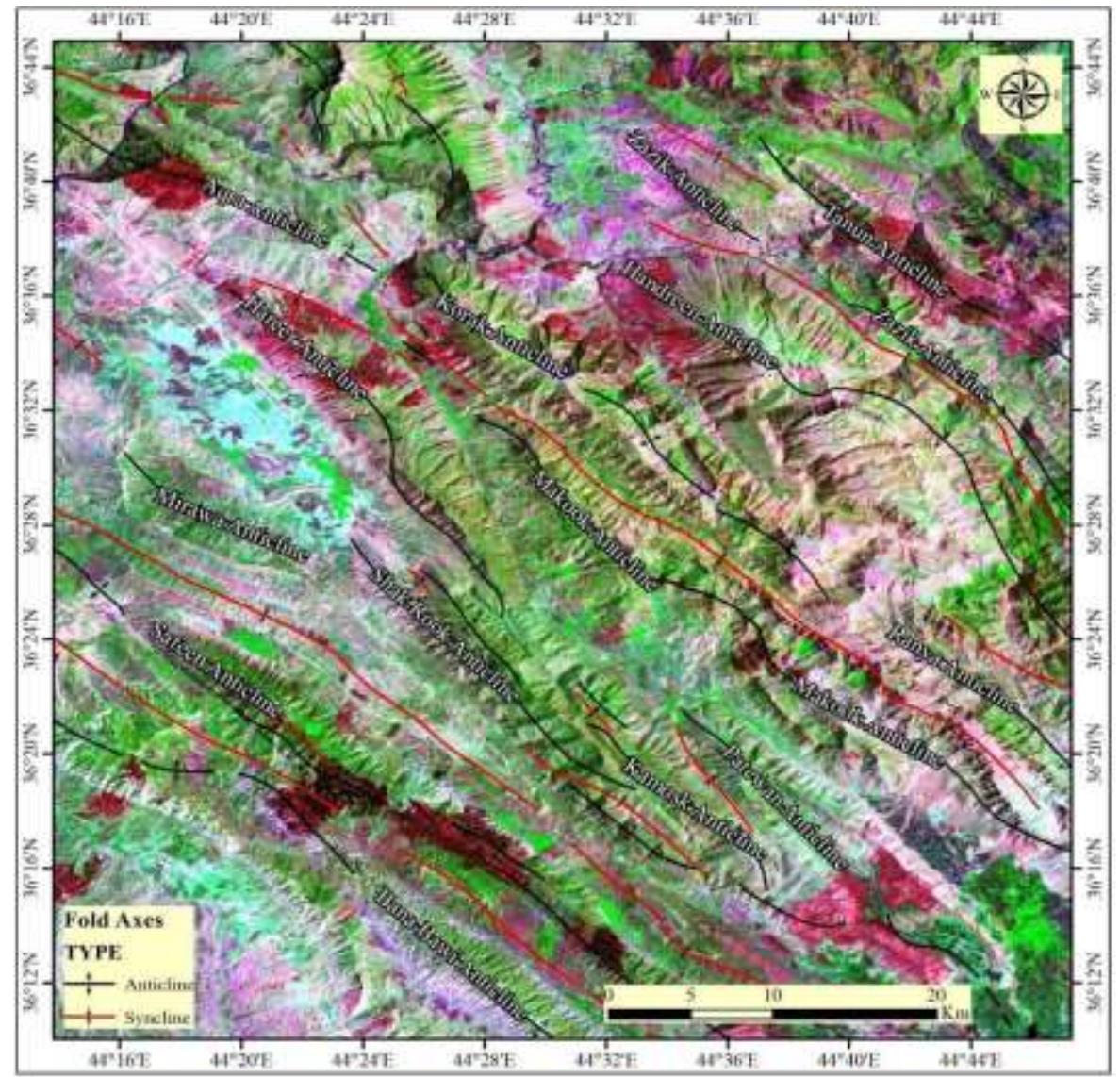

Figure 5-Digital Elevation Model (DEM) of the Shakrok and Merawa anticlines. 
The fold plunged northwestern near Merawa anticline site (Figure-6), and the southestern plunge is overlap with the northwestern plunge of Shakrok anticline which is represented by the thrusting graben syncline (Figure-7).

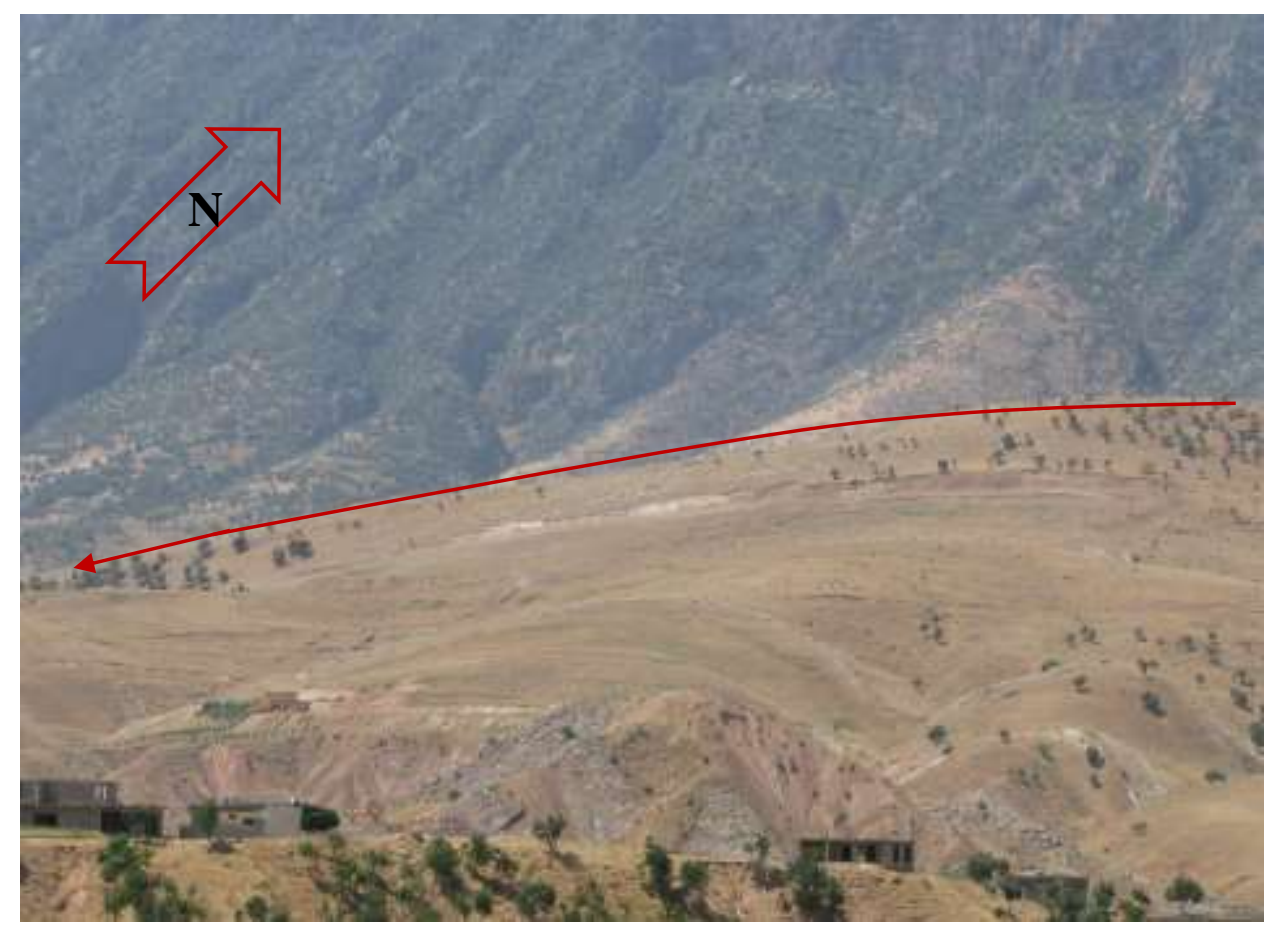

Figure 6-Field photo of the study shows fold plunged northwestern.

The attitude of the fold is composed mostly of Aqra/Bekhme, Shiranish and Tanjero Formations Figures-(7, 8). Whereas Qamchuqa Formation exposed only in the center of the structure (Figure-9), which are obvious along the cutting valley that's connect both sides of the anticline. Injana Formation is represented the covering of the syncline between Merawa - Shakrok anticlines to southeast side and Harir-Shakrok anticlines (Figure-10).

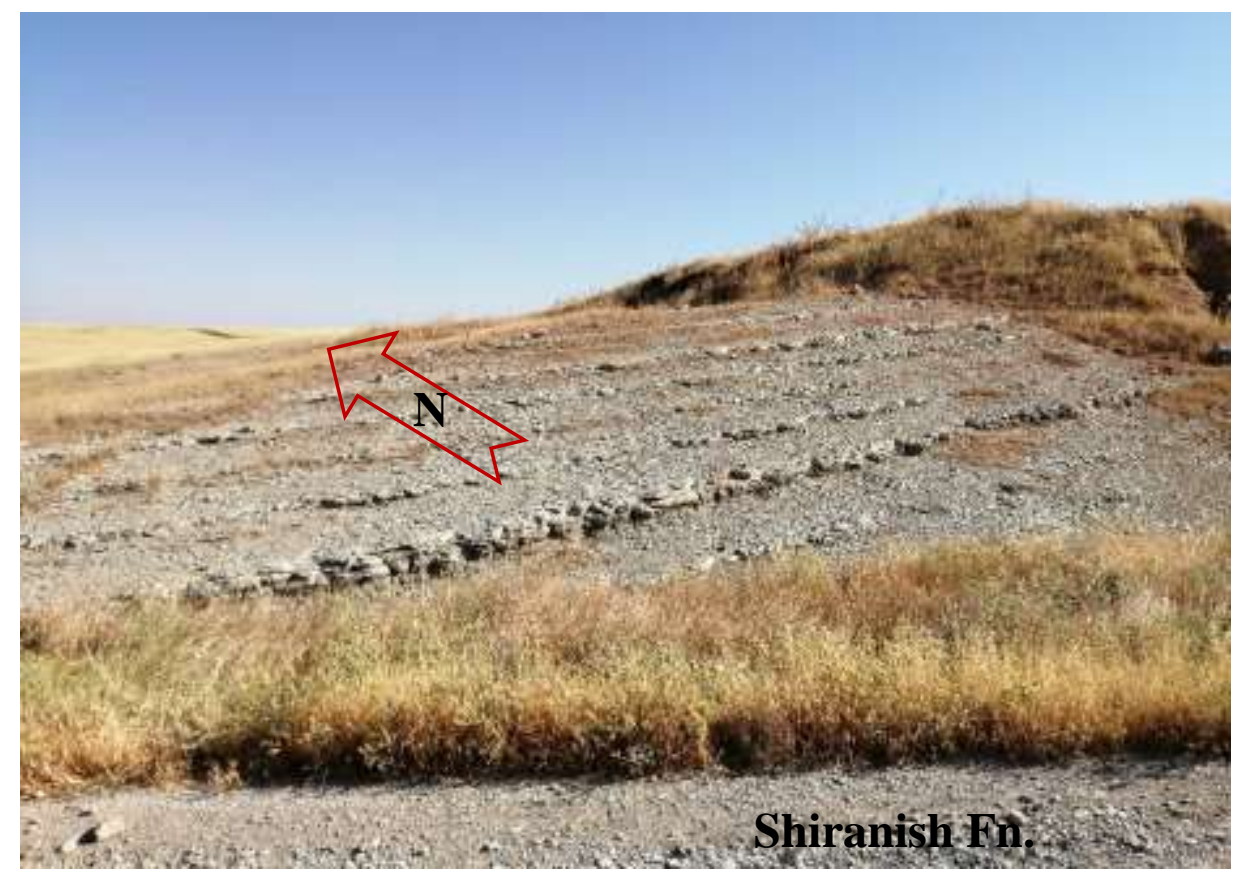

Figure 7-Shiranish Formation in Southwestern plunge of Shakrok anticline near Merawa city 


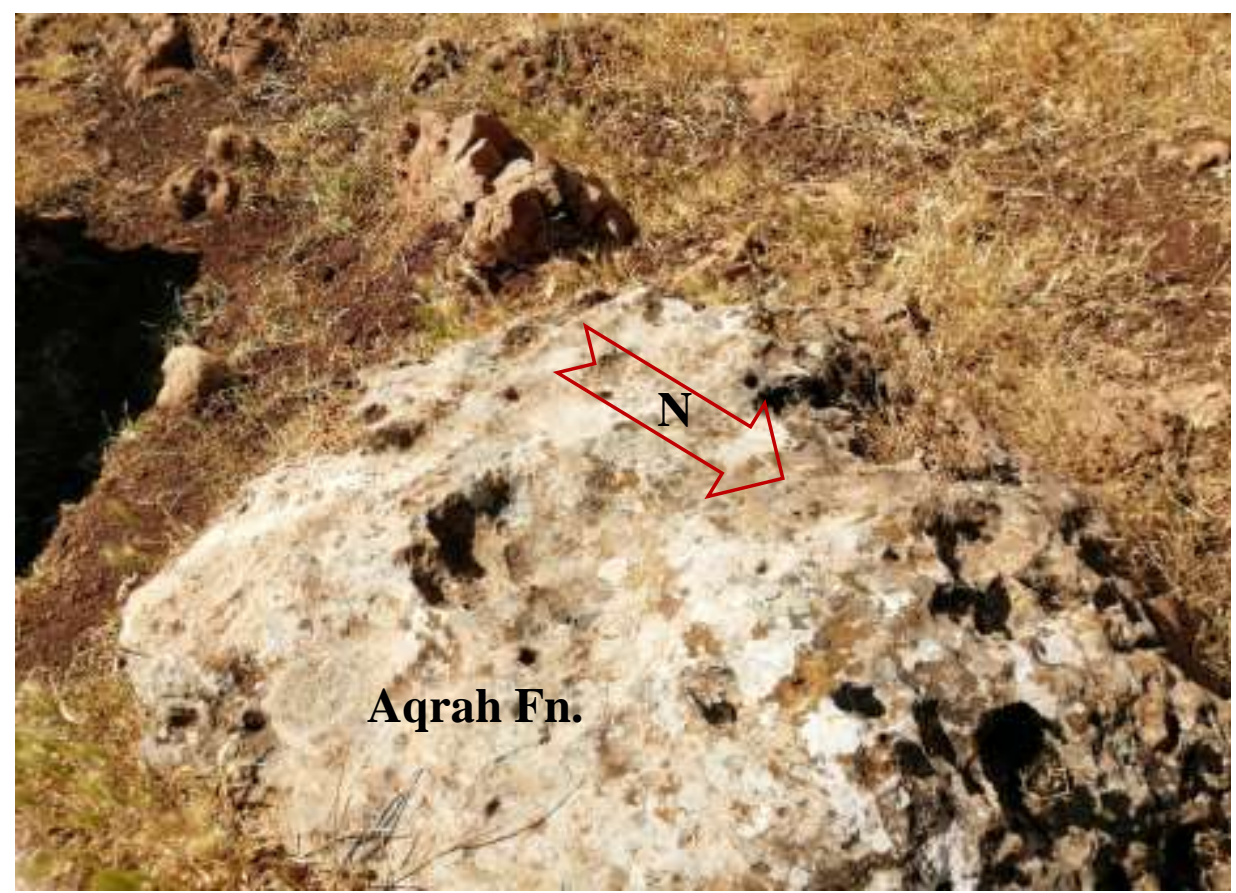

Figure 8-Aqra Formation in Southestern limb of Shakrok anticline.

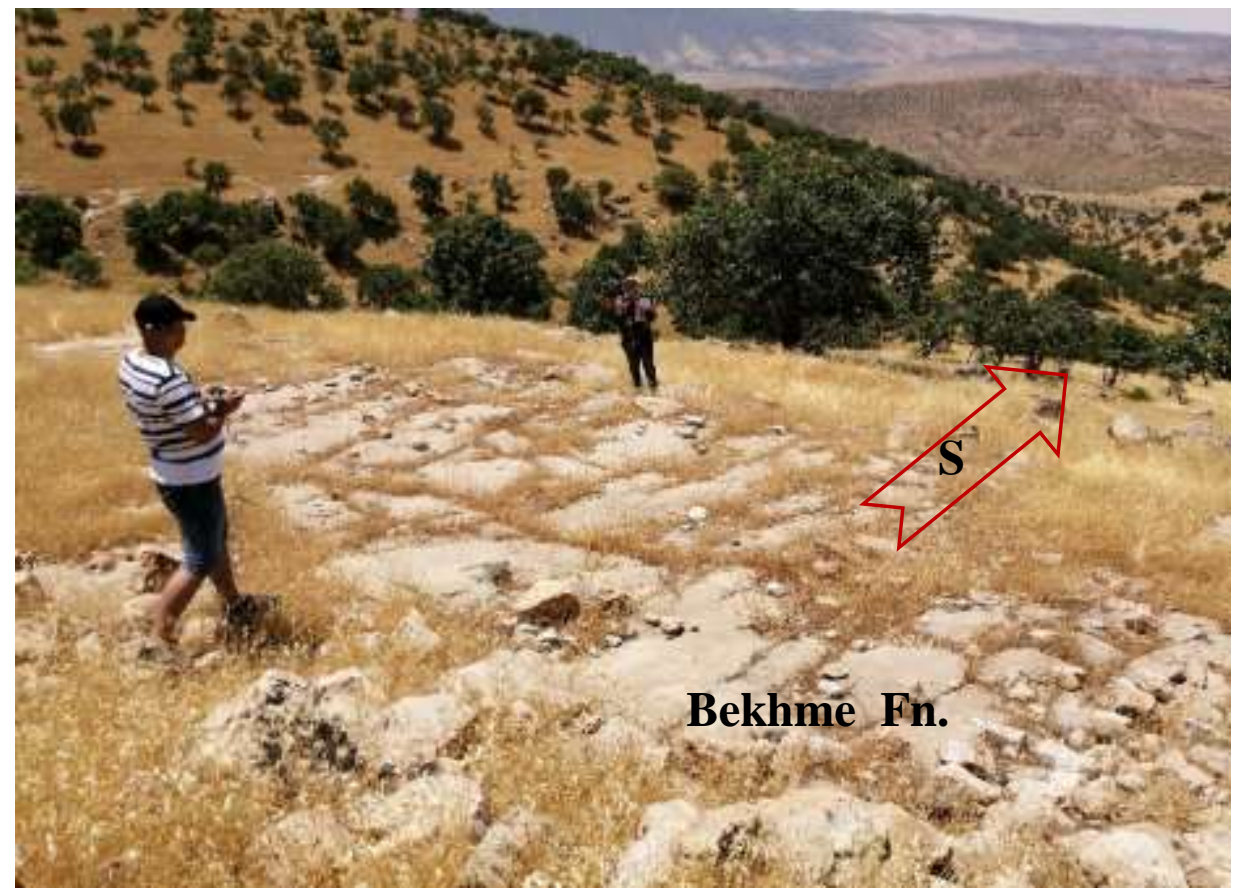

Figure 9-Bekhme Formation in Southeastern limb of Shakrok anticline 


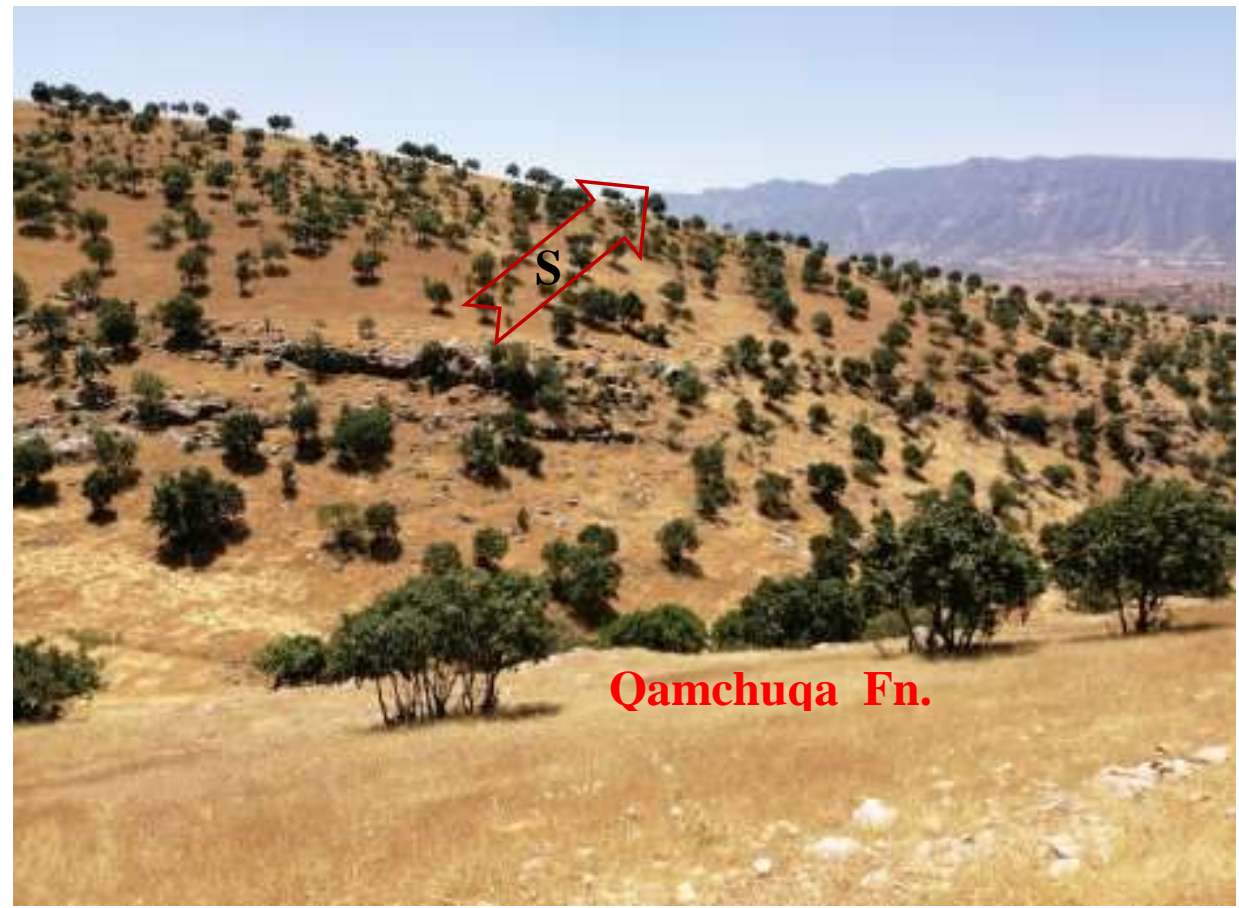

Figure 10-Qamchuqa Formation in the core of Shakrok anticline

\section{Geometric Analysis:}

Number of measurements of bedding planes were taken from Shiranish, Aqra and Bekhma formations in the southwestern and northeastern limbs of the studied anticline. That is because the Tertiary Formations were not found in this area. Geometrical analysis of these measurements using GEOrient, V.9.5.0 and GeoCalculator V.4.9.7 software revealed the geometrical attitude of this fold. Figures-(11, 12) shows a synoptic stereographic pi-diagram of Shakrok Anticline.
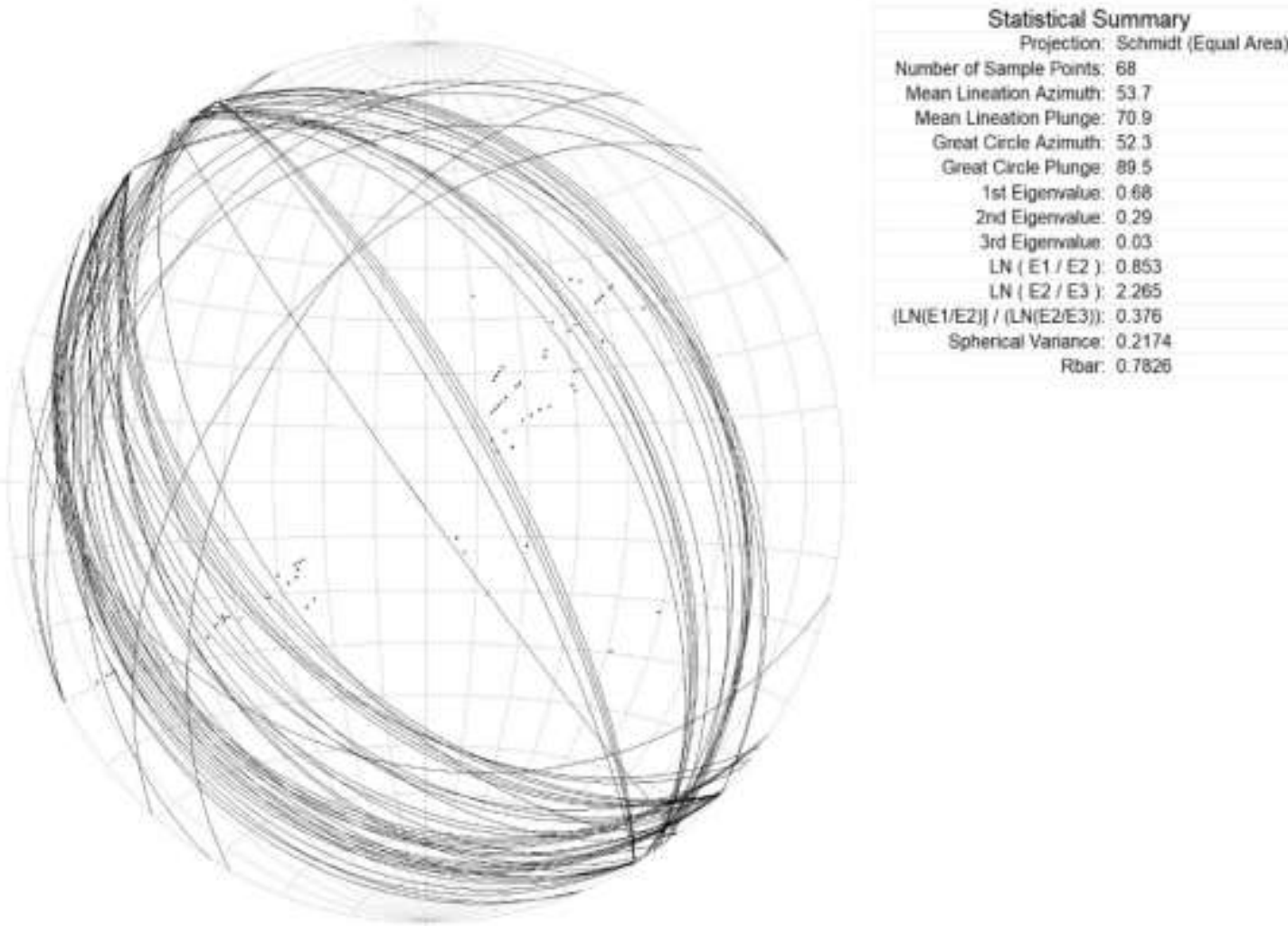

Statistical Summary Projection: Schmidt (Equal Area Number of Sample Poims; 68 Mean Lineation Azimuth: 537 Mean Lineation Plunge: 70.9 Grest Circic Azimuth. 523 Great Circle Plunge; 89.5 ist Eigenvalue. 0.68 2nd Eigerratue. 0.29 Ird Figernalian: 0.03 LN (E1/E2) 0.853 LN (E2/E3) 2.265 [LNIE1/E2)] / (LN(E2E3): 0.376 Spherical Variance: 0.2174 Rbar. 0.7826

Figure 11-Synoptic stereographic pi-diagram of the Shakrok anticline 


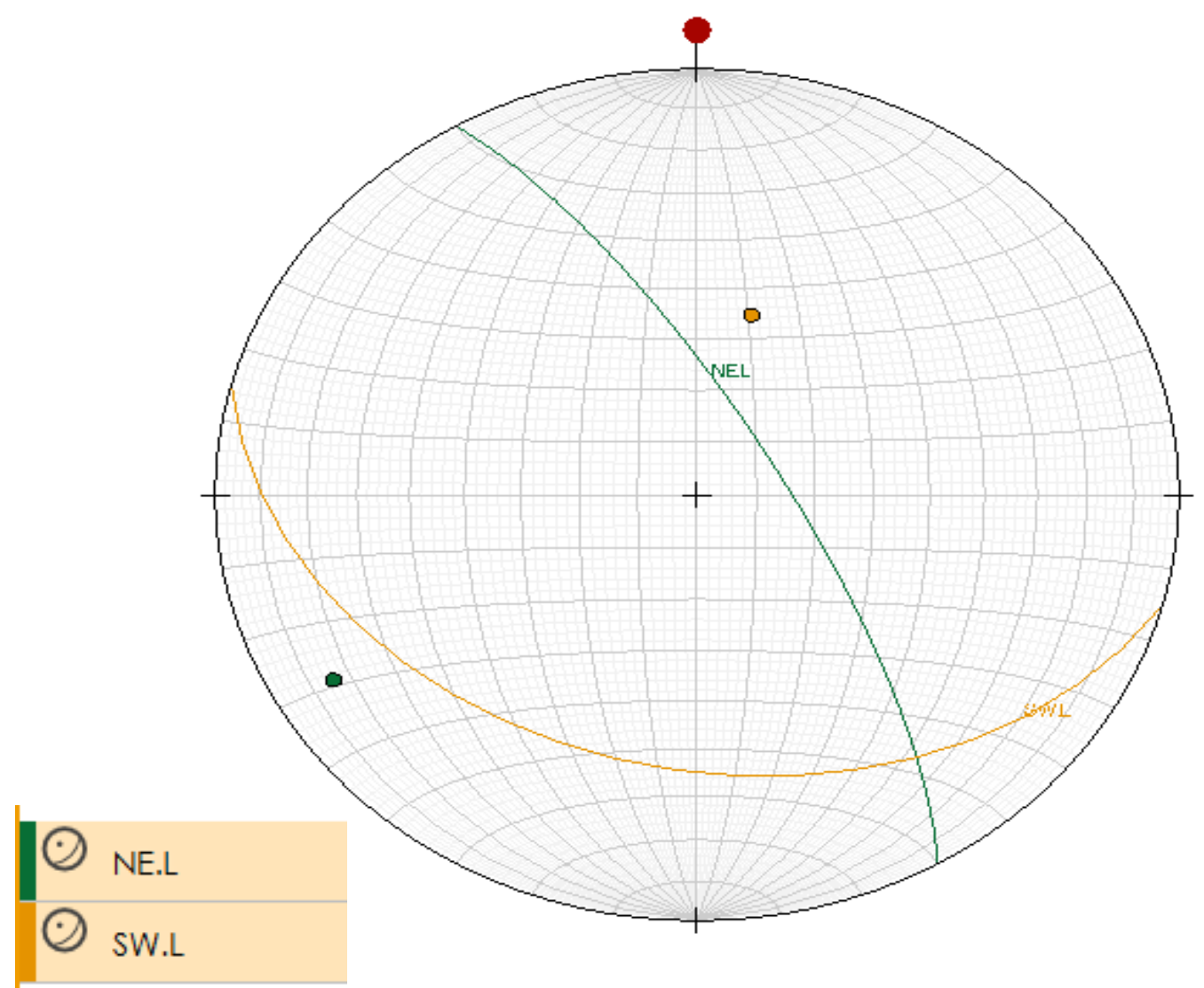

Figure 12-Average Synoptic stereographic pi-diagram of the study area

It can be seen from the stereogram that the anticline has a northeastward vergence, fold axis attitude in terms of trend and plunge is $325^{\circ} / 12^{\circ}$, axial plane attitude is $057^{\circ} / 85^{\circ}$ as dip direction and dip amount, interlimb angle is $140^{\circ}$ and the fold is classified as Gentle fold according to Fleuty, 1964 classification, the average attitude of the northeastern limb is $066^{\circ} / 40^{\circ}$ in form of dip direction and dip amount, whereas the southwestern one is $225^{\circ} / 38^{\circ}$. Bedding plane attitudes that were measured and taken from different formations in both limbs of Shakrok Anticline along the traverses were plotted in Stereographic Projection to get the mean attitude of the bedding planes of the anticline in order to find the limbs dips, axial surface, and axis attitude in addition to interlimb angle for each formation. Figure-13 shows the attitudes of the formations bedding planes for both limbs of the anticline. 


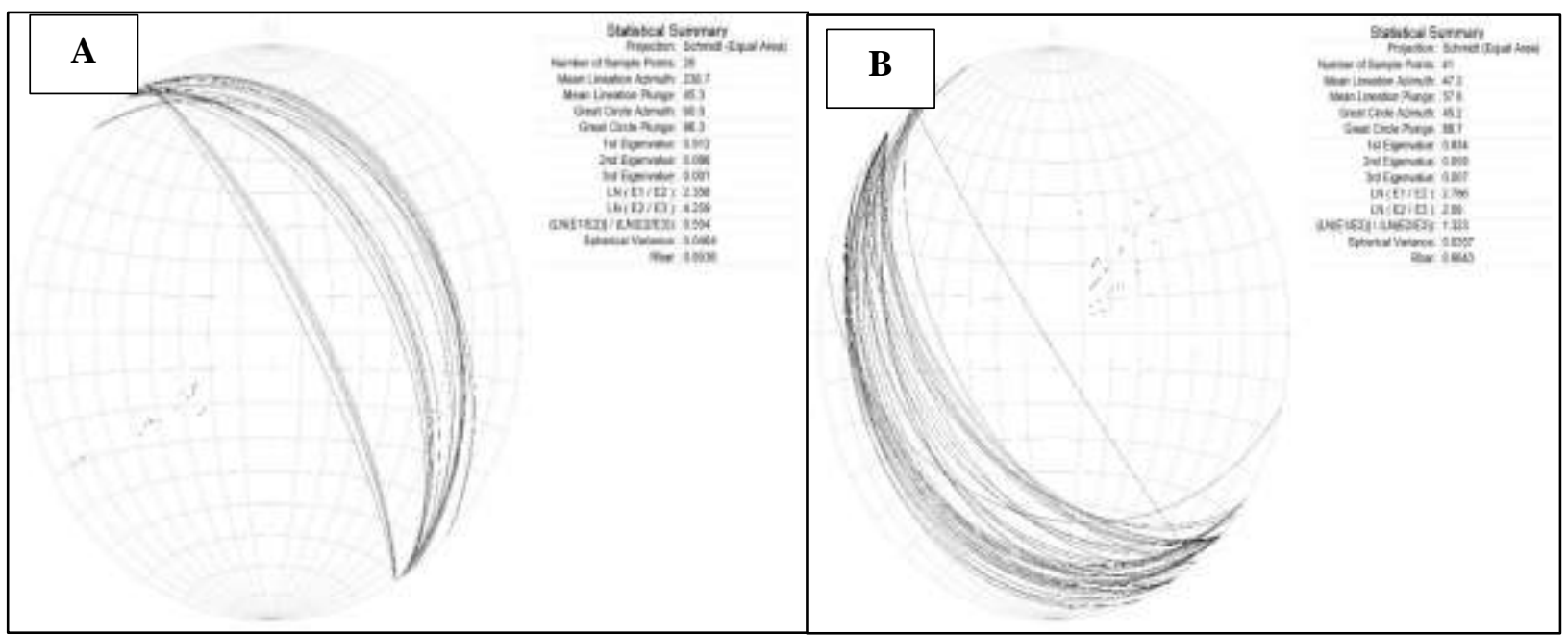

Figure 13-shows the attitudes of the formations bedding planes for both limbs of the anticline A. NE limb B. SW limb.

\section{Geometrical Description:}

The geometric description of the anticline was carried out for each traverse by the revealing results that obtained from the field measured data and process results that came out with the values of the Interlimb angle, Fold axis and Axial plane attitudes for each traverse and each formation (representing same age) of Shakrok Anticline. Figure-14 is a stereographic pi-diagrams for the studied Anticline showing the fold axis and axial plane. Therefore, according to Fleuty, 1964 [11]fold classification the fold could be classified as Gentle fold.

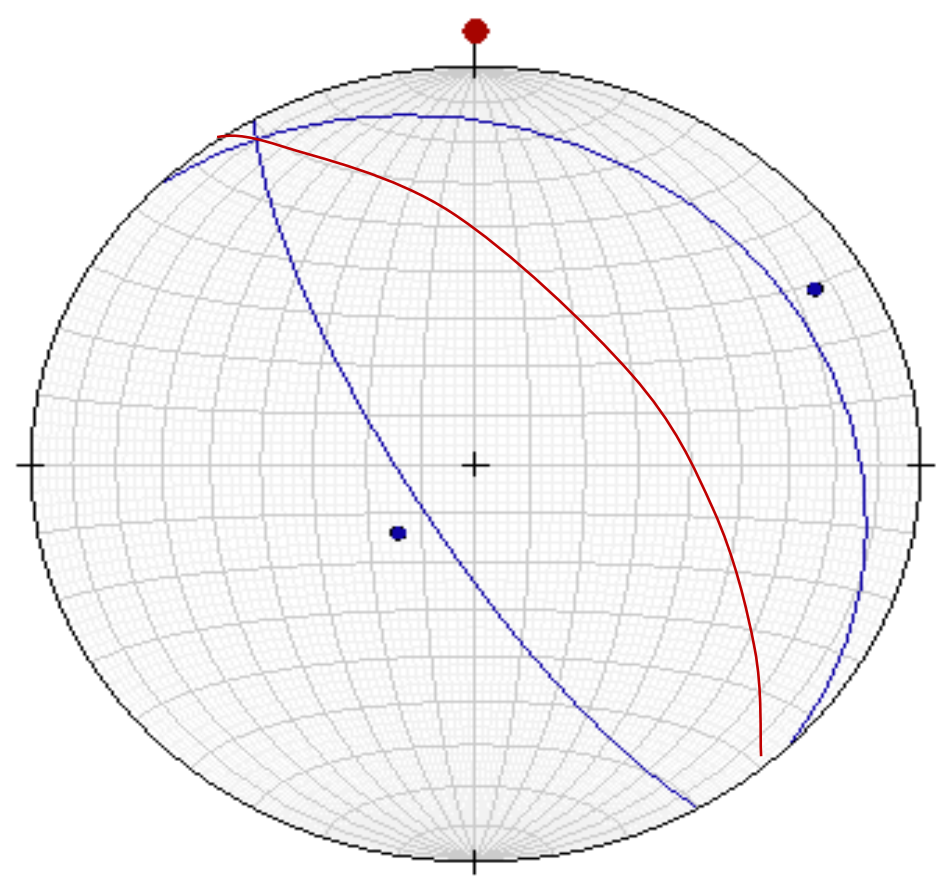

Interlimb Angle $=226^{\circ}$

Fold Axis $=140^{\circ} / 10^{\circ}$

Axial Plane $=050^{\circ} / 63^{\circ}$

$\mathrm{SW} \operatorname{Limb}($ mean $)=330^{\circ} / 77^{\circ}$

$\mathrm{NE} \operatorname{Limb}($ mean $)=135^{\circ} / 20^{\circ}$

Figure 14-stereographic pi-diagrams for interlimb angle and fold axis and axial plane in the Shakrok Anticline 
There are two patterns of geometrical distribution in the studied area:-

a. Shiranish Formation in the NE, SW and Plunging

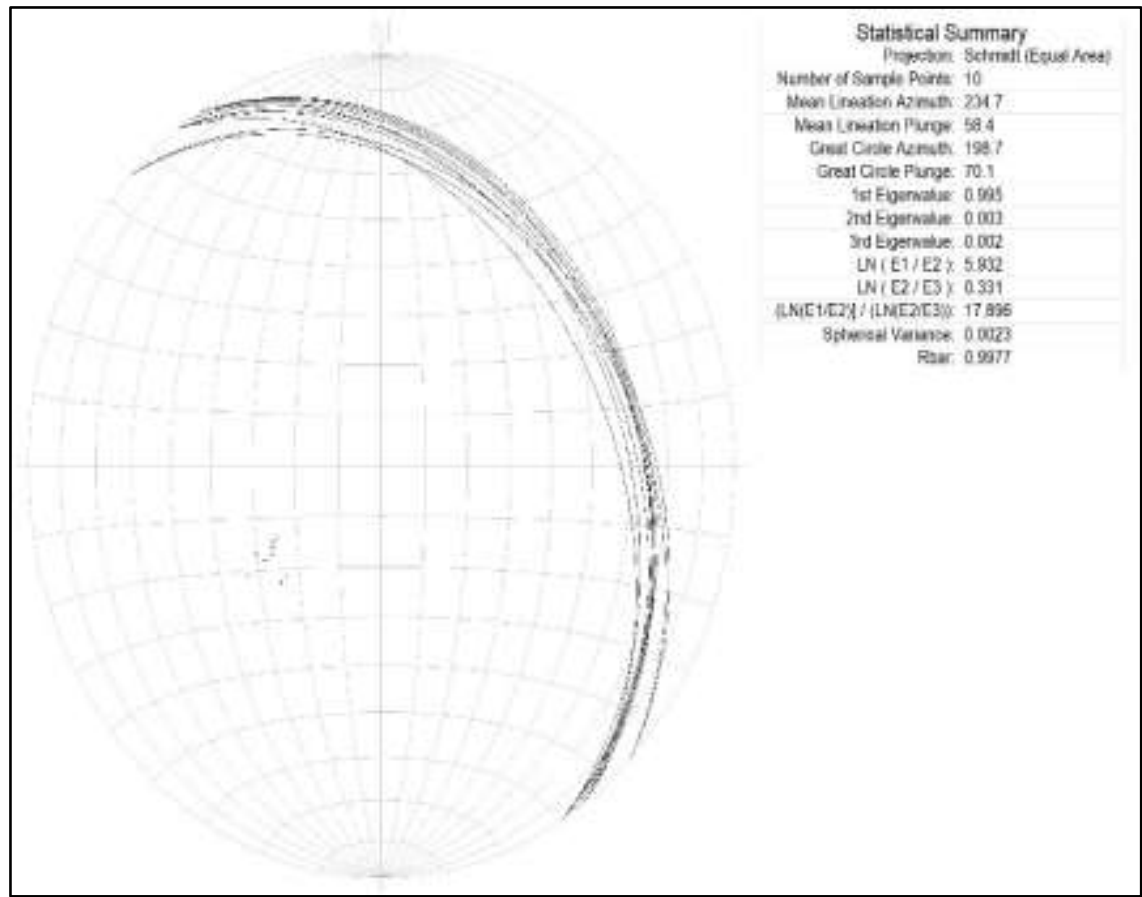

NE limb

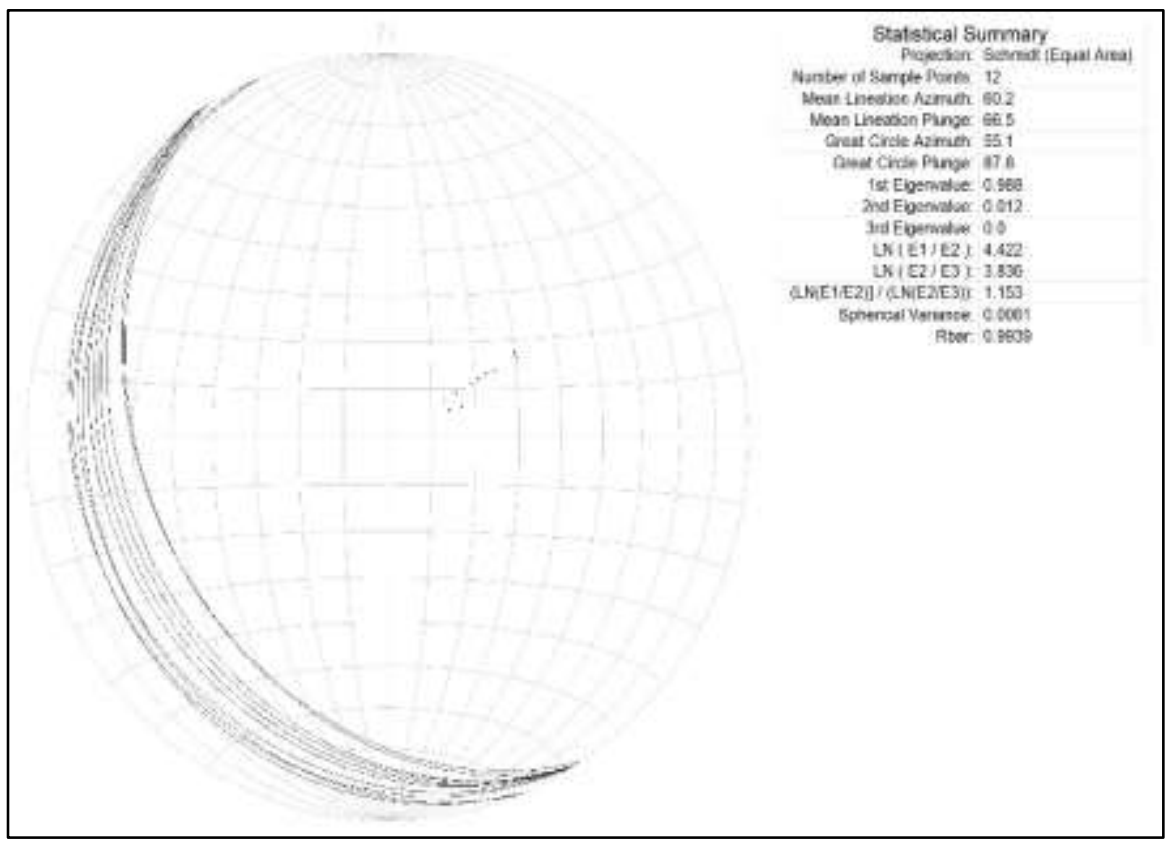

SW limb 


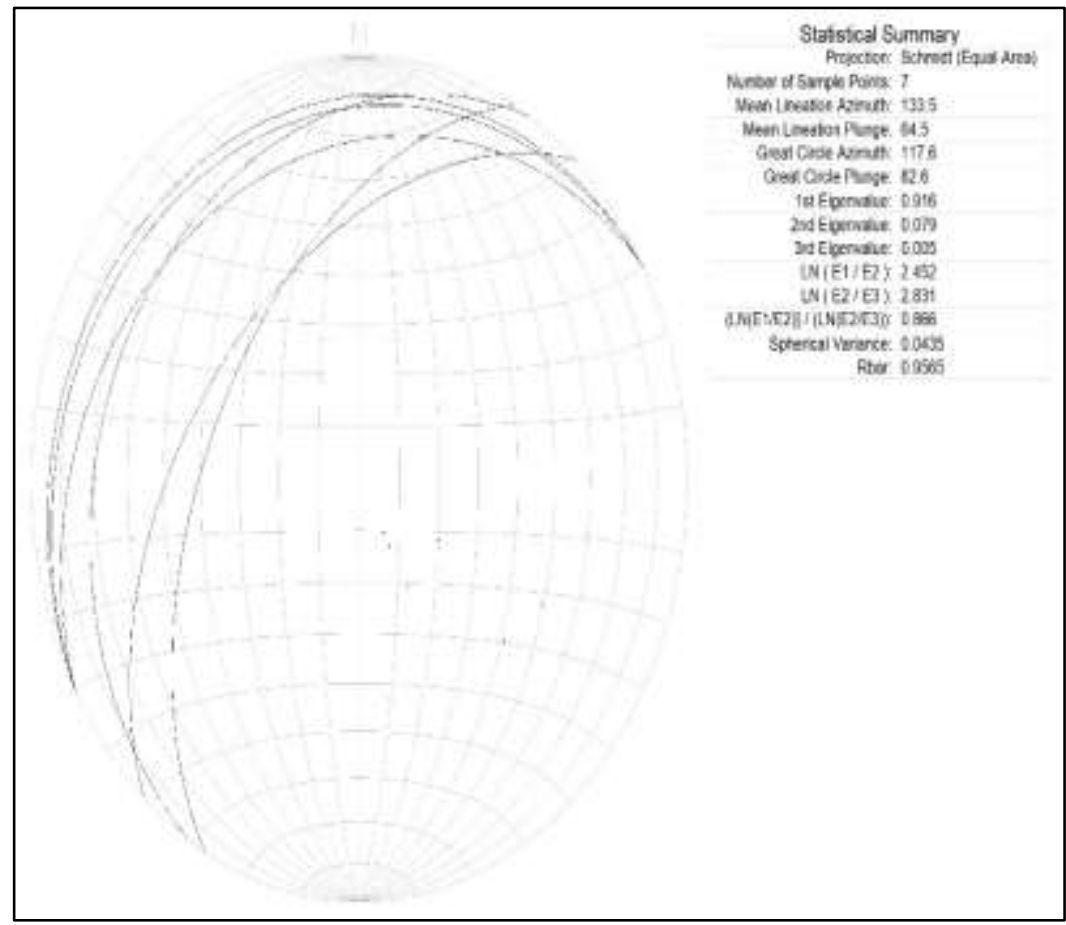

Plunging

b. Aqrah/Bekmah Formation in the NE and SW

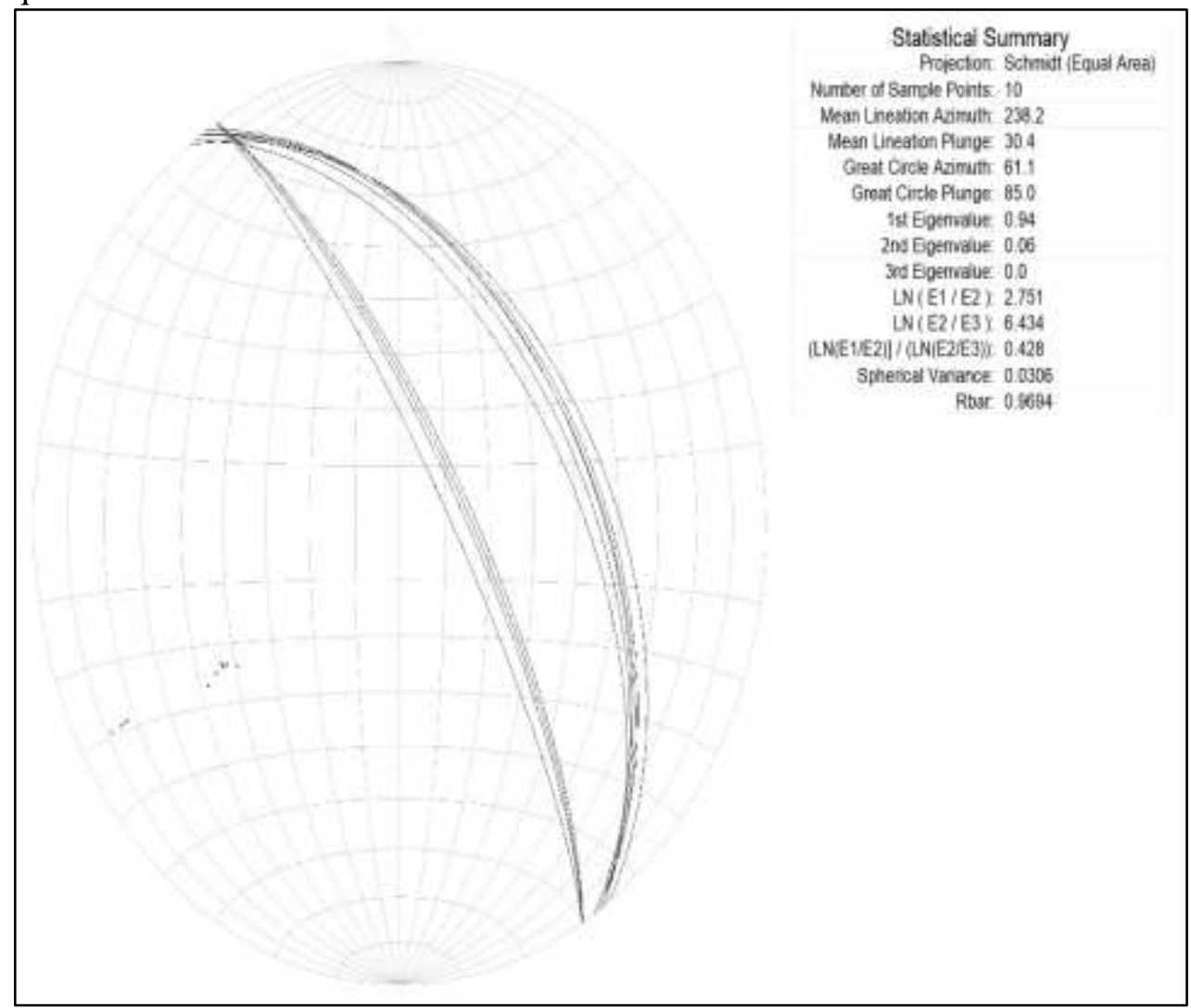

NE limb 


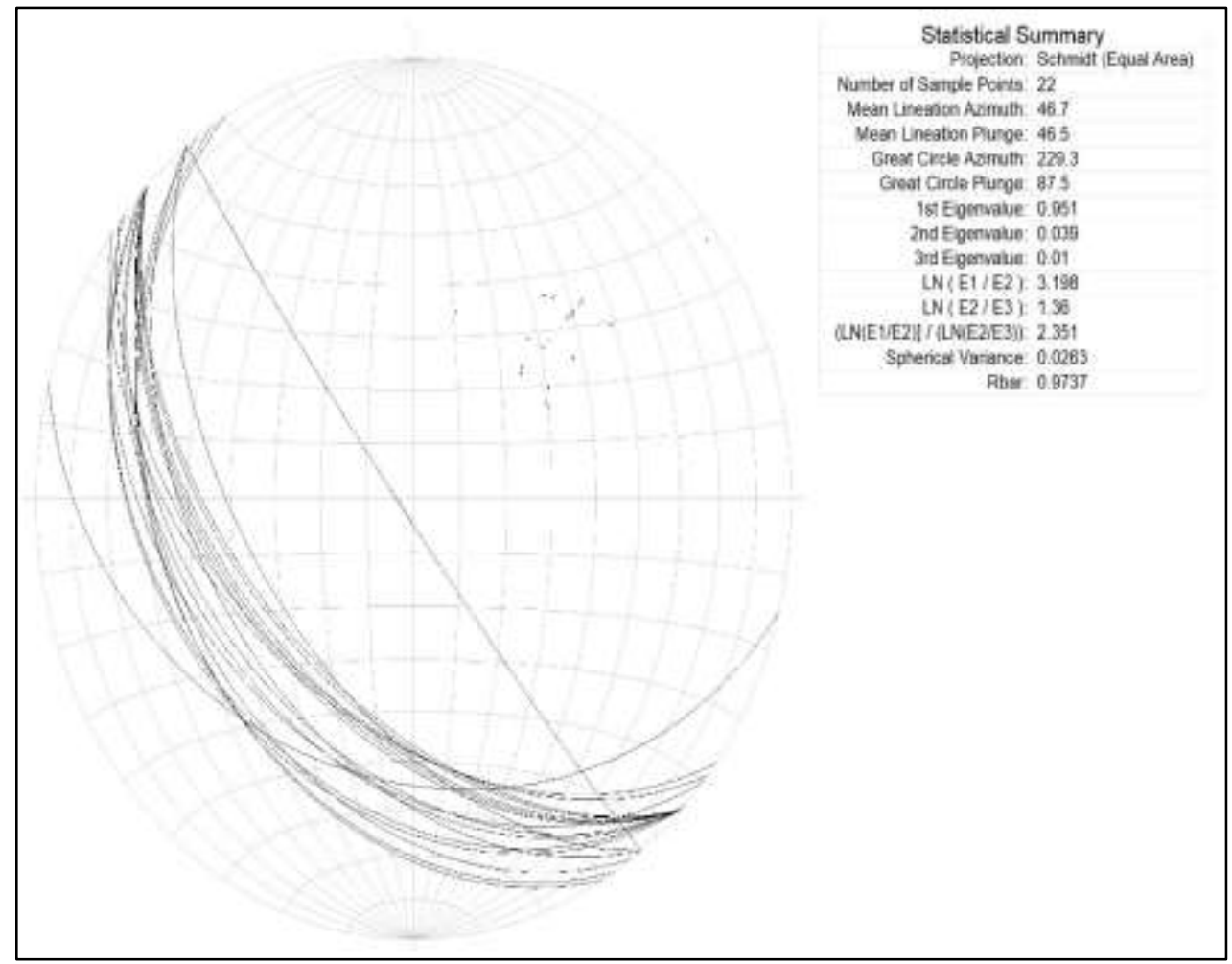

SW limb

\section{Conclusion}

The studied area is a part of the Arabian plate located within the high folded zone of the Zagros Fold-Thrust Belt in northeastern Iraq (Kurdistan Region). The study area that represents Shakrok Anticlines lies between Safin and Sork Mountains. These structures are formed during the Alpine Orogeny in Cretaceous-Tertiary age. Generally, the folded structures are trending NW-SE direction which is parallel the main Zagros Orogenic trends.

Shakrok Anticline are asymmetrical, double plunging and verging toward northeast. This establishes that Khatibian is a Tertiary continuation part of Cretaceous Shakrok Anticline. But there is a deflection in the direction of the fold axis that affected on the Merawa Anticline due to the effect of strike slip fault addition to Lineaments. Shakrok Anticline with Cretaceous successions formed due to the effect of Cretaceous and Tertiary folding phases. But Merawa Anticline with Tertiary succession formed due to the effect of Tertiary folding phases.

The high stress and intensity of the major fault on the southwestern limb have rotated and overturned Tertiary successions and changed its dip toward NE.

The differences in fold geometry, fold axis, axial surface, and curvilinear hinge imply that the structure formed as a result of two folding phases \& lateral growth of folds that developed by changing the direction of the compressional tectonic processes due to Alpine Orogene of Zagros. The fold axis of Shakrok Anticline rotated $16^{\circ}$ in anticlockwise trend from Merawa to Sork anticlines. Because of anticlockwise rotation of the Arabian plate due to its collision with Iranian and Anatolian plates.

\section{References}

1. Fouad, S.F. 2014. Tectonic Map of Iraq, Scale 1 1000000. 3rd Edition, Iraq Geological Survey (GEOSURV) Publications, Baghdad.

2. Zebari, M. 2013. Geometry and evolution of folded structures within the high folded zone: Zagros Fold-Thrust belt, Kurdistan Region- Iraq, Unpub. MSc. Thesis, University of Nebraska-Lincoln, 91p.

3. Jassim, S. Z. and Goff, J. C. 2006. Geology of Iraq: Dolin, Prague and Moravian Museum, Brno, Czech Republic. 
4. Syan S. H. 2014. Tectonic Criteria from Shortening Estimation in different geological time and space using Balancing Cross Sections in the Harir and Khatibian Anticlines, Zagros Fold-Thrust Belt, Kurdistan of Iraq. College Of Science - Salahaddin University - Erbil In Partial. Unpublish thesis, 130p.

5. Ameen, B.M. 2008. Sedimentology and Lithostratigraphy of Qamchuqa Formation from Kurdistan Region,NE-Iraq.Unpub. PhD thesis, University of Sulaimani, Iraq, 143 p.

6. Al-Shaikh, Z. D. and Saleh, S. A. \& Abdo, H. F. 1975. Contribution to the geology of ShaqlawaHarir area. Journal of the geo. Society of Iraq, Spacial Issue, pp: 55-67.

7. Abdallah F.T, Al-Dulaimi S.I. 2019. Biostratigraphy of the Upper Cretaceous for selected sections in northern Iraq. Iraqi Journal of Science, 60(3): 545-553.

8. Ahmed M.J., Tamar-Agha M.Y. and Alwan T.A. 2017. The Sedimentology and Facies Analysis of the Cretaceous Oceanic Red Beds (CORBs) in the Shiranish Formation, Northern of Iraq. Iraqi Journal of Science, 58(3A): 1220-1234

9. Ghaib, F. A., 2004. Geo-electrical investigation in Harir plain northeast ofErbil City, Iraqi Journal of Earth Sciences, 4(2): 31-43, Mosul University (Iraq).

10. AL-Dawoody, A. N. 2004. A gravity study in the Harir area (Iraqi Kurdistan region). Unpub. M.Sc. thesis, University of Salahaddin, 89p.

11. Omar, A. A. 2005. An integrated structural and tectonic study of the Bina Bawi-Safin-Bradost Region: Unpub. Ph.D. thesis, Salahaddin University, Erbil. 300p.

12. Fleuty, M. J. 1964. The description of folds. Geol. Assoc. Lond. Proc.75: 461-492. 